\title{
Article \\ The Stoichiometry, Structure and Possible Formation of Crystalline Diastereomeric Salts
}

\author{
Dorottya Fruzsina Bánhegyi (D) and Emese Pálovics* \\ Department of Organic Chemistry and Technology, Budapest University of Technology and Economics, \\ 1521 Budapest, Hungary; banhegyi.dorottya.fruzsina@vbk.bme.hu \\ * Correspondence: emese.palovics@vbk.bme.hu
}

check for updates

Citation: Bánhegyi, D.F.; Pálovics, E. The Stoichiometry, Structure and Possible Formation of Crystalline Diastereomeric Salts. Symmetry 2021, 13, 667. https://doi.org/10.3390/ sym 13040667

Academic Editor: Takashiro Akitsu

Received: 25 March 2021

Accepted: 9 April 2021

Published: 13 April 2021

Publisher's Note: MDPI stays neutral with regard to jurisdictional claims in published maps and institutional affiliations.

Copyright: (C) 2021 by the authors. Licensee MDPI, Basel, Switzerland. This article is an open access article distributed under the terms and conditions of the Creative Commons Attribution (CC BY) license (https:/ / creativecommons.org/licenses/by/ $4.0 /)$.

\begin{abstract}
Knowing the eutectic composition of the binary melting point phase diagrams of the diastereomeric salts formed during the given resolution, the achievable $\mathrm{F}\left(\mathrm{F}=\mathrm{ee}_{\mathrm{Dia}}{ }^{*} \mathrm{Y}\right)$ value can be calculated. The same value can also be calculated and predicted by knowing the eutectic compositions of the binary melting point phase diagrams of enantiomeric mixtures of the racemic compound or the resolving agent. An explanation was sought as to why and how the crystalline precipitated diastereomeric salt-formed in the solution between a racemic compound and the corresponding resolving agent-may be formed. According to our idea, the self-disproportionation of enantiomers (SDE) has a decisive role when the enantiomers form two nonequal ratios of conformers in solution. The self-organized enantiomers form supramolecular associations having $\mathrm{M}$ and $\mathrm{P}$ helicity, and double helices are formed. Between these double spirals, with the formation of new double spirals, a dynamic equilibrium is achieved and the salt crystallizes. During this process between acids and bases, chelate structures may also be formed. Acids appear to have a crucial impact on these structures. It is assumed that the behavior of each chiral molecule is determined by its own code. This code validates the combined effect of constituent atoms, bonds, spatial structure, charge distribution, flexibility and complementarity.
\end{abstract}

Keywords: predictable resolution; supramolecular associations; helical structure; eutectic composition

\section{Introduction}

When a racemic mixture (SR) reacts in a solution with a suitable chiral compound $\left(R^{*}\right)$, depending on the solvent, one of the diastereomers precipitates (e.g., crystalline SR ${ }^{*}$ ) and the other remains in solution ( $R^{*}$ solution). The multiplication of the purity (ee yield $(\mathrm{Y})$ of the enantiomeric mixture, which is isolated from the precipitated diastereomer, gives the selectivity $\left(\mathrm{F}=\operatorname{ee}_{\mathrm{Dia}}{ }^{*} \mathrm{Y}\right)$. $\mathrm{F}$ corresponds to the enantiomeric ratio of the mixture (in addition to the racemic ratio).

When the binary melting point phase diagram of the racemic mixture is constructed, a relationship between the eutectic composition $\left(\mathrm{ee}_{\mathrm{Eu}}\right)$ and the results can be observed (Figure 1) [1].

We have also shown experimentally [1] that under certain conditions the purity of the enantiomeric mixtures separable from the precipitated diastereomeric salt is approximately equal to the eutectic composition of the enantiomeric mixtures of the racemic compound or the eutectic composition of the enantiomeric mixtures of the resolving agent (ee ${ }_{\mathrm{Dia}} \sim \mathrm{ee}_{\mathrm{EuRac}}$ or $\left.\mathrm{ee}_{\mathrm{Dia}} \sim \mathrm{ee}_{\mathrm{EuRes}}\right)$. 


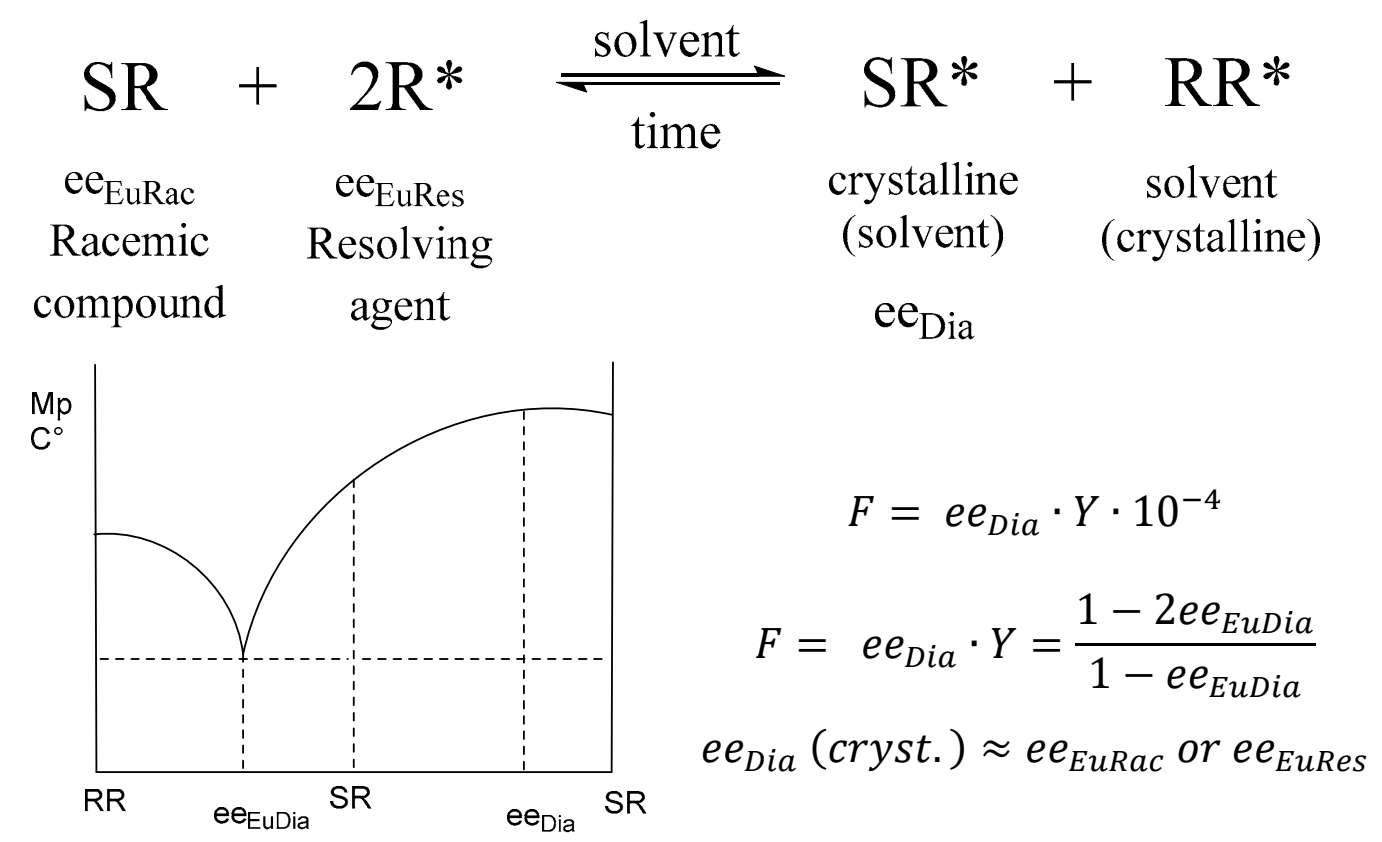

Figure 1. Binary melting point phase diagram of diastereomeric mixtures and stoichiometry of diastereomers (ee $e_{\text {euRac }}$ : ee of an enantiomer at the eutectic composition of the racemic compound; ee $_{\text {euRes }}$ : ee of the resolving agent enantiomer $(R)$ at the eutectic composition; ee ${ }_{\text {Dia }}$ : ee of the enantiomer of the original racemic compound at the eutectic composition of the diastereoisomeric salt).

The enantiomers-whose separation possibilities are summarized in this article-have been used for the synthesis of active pharmaceutical ingredients (Jumex, prostaglandins, aspartame, Chlorocid, antibiotics). During the resolution of these compounds, further insights have been added to our previous knowledge.

\section{The Stoichiometry of the Crystalline Diastereomeric Salt May Be Determined by the Eutectic Composition of Either the Racemic Compound or the Resolving Agent}

Based on our own [2-4] and others' experimental results regarding the self- disproportionation of enantiomers (SDE) [5-16], we were looking for an explanation of the possible mechanism for the distribution of the enantiomeric diastereomeric mixtures between solid-liquid phases.

However, there was no explanation of how it is possible to form the eutectic composition of the single enantiomer resolving agent from the enantiomers of the racemic compound present. We believe that this is only possible if at least two reactive conformers of the single enantiomer resolving agent react with the enantiomers of the racemic compound.

It was demonstrated that two types of conformers are involved in the crystalline structure of the enantiomers, roughly mimicking the stability of the corresponding racemic structure [17]. Racemic tofizopam tends to form an 82:18 (major/minor) conformer ratio immediately in chloroform solution. The single enantiomer is also capable of this phenomenon, but it takes $48 \mathrm{~h}$ if its enantiomeric pair is not present [18].

It was also shown that in the crystal structure of the diastereomeric salt, the resolving agent (sodium salt of cis-2-hydroxycyclopent-4-enyl acetic acid (CPN) intermediate of the prostaglandin $\mathrm{F}_{2 \alpha}$ synthesis) participates with two conformers in a ratio of 59:41 and thus achieves high purity of the corresponding enantiomer from the racemic compound in the diastereomer (Figure 2) [19]. 
<smiles>C[C@H](N)c1ccccc1</smiles>

S-PhEA<smiles>C[C@H](N)c1ccccc1</smiles>

R-PhEA<smiles>[PH3-]</smiles><smiles>O=C(CC1C=CCC1O)O[Na]</smiles>

\section{$\mathrm{H}_{2} \mathrm{O}$}

(1S,5R)-CPN
$R$-PhEA.(1S,5R)-CPN

$F: 0.51$

\section{The ratio of conformers}

$59 / 41$

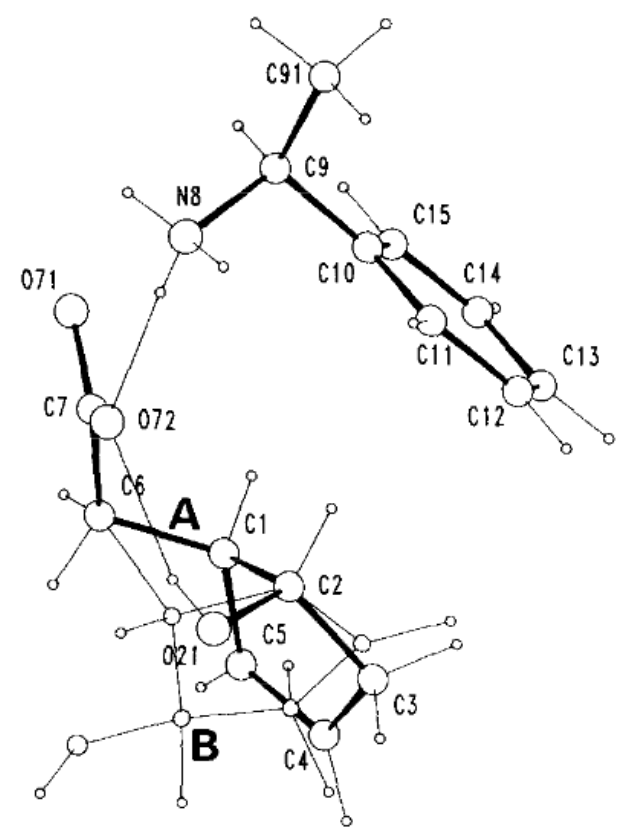

Figure 2. Separation of 1-phenylethan-1-amine hydrochloride (PhEA) enantiomers by the sodium salt of (1S,5R)-CPN and perspective view of the asymmetric unit in the (R)-PhEA.(1S-5R)-CPN salt aggregate. Thick lines indicate major (conformer A with 59\% population) while thin lines the minor (conformer B with $41 \%$ population) orientation in the hydroxycyclopentenyl part of the anion.

Accordingly, the assumption has been proved that the stoichiometry of the diastereomeric salts formed by the reaction of the racemic compound with the resolving agent can be determined by the racemic compound or the resolving agent. It may also provide the stoichiometry of the diastereomer by the ratio of the resolving agent conformers (ee Dia value). This is illustrated by a generalized example and figure (Figure 3).

Two conformers ( $\mathrm{M}$ and $\mathrm{P}$ ) of each chiral molecule are formed in the reaction mixture of the resolution and form supramolecular helical structures. The ratio of conformers depends on the eutectic composition $\left(\mathrm{M}: \mathrm{P} \sim \mathrm{ee}_{\mathrm{Dia}}\right)$. Therefore, $\mathrm{ee}_{\mathrm{EuRes}}$ have the potential to determine the stoichiometry of the crystalline precipitation.

The reaction of racemic methamphetamine (2-methylamino-1-phenylpropane, MeAn) with $(R, R)$-tartaric acid (TA) (Figure 4$)$ produces the $(R)$-MeAn. $(R, R)$-TA diastereomeric salt from an aqueous solution. From the diastereomeric salt, $(R)-$ MeAn (ee $\mathrm{Dia}: 95 \%)$ can be isolated with high purity. Based on single-crystal X-ray diffraction of the diastereomeric salt (Figure 5), the crystalline $(R)$-MeAn. $(R, R)$-TA forms an antiparallel double helix. 

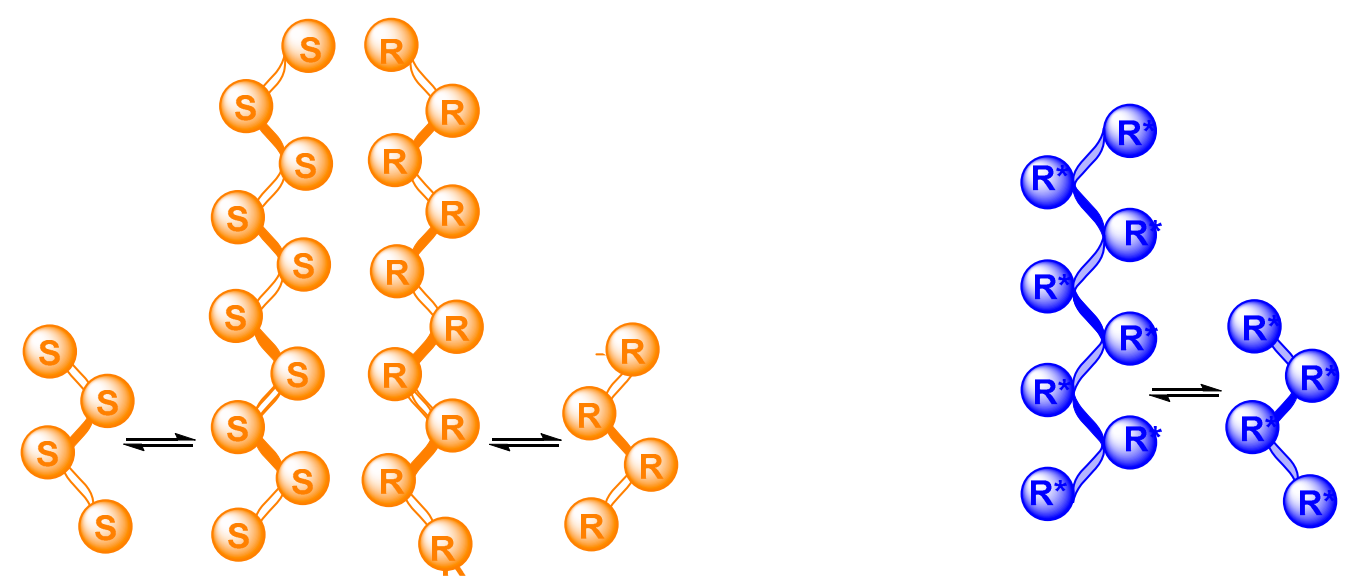

M S

P S M R

P S

$P^{*} \quad M R^{*}$

$\operatorname{ee}_{\text {EuRac }}: 71 \%$

ee $_{\text {EuResAg }}: 67 \%$

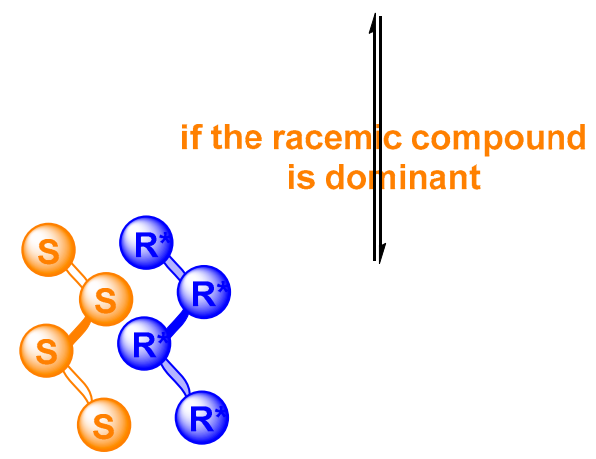

M S M R*
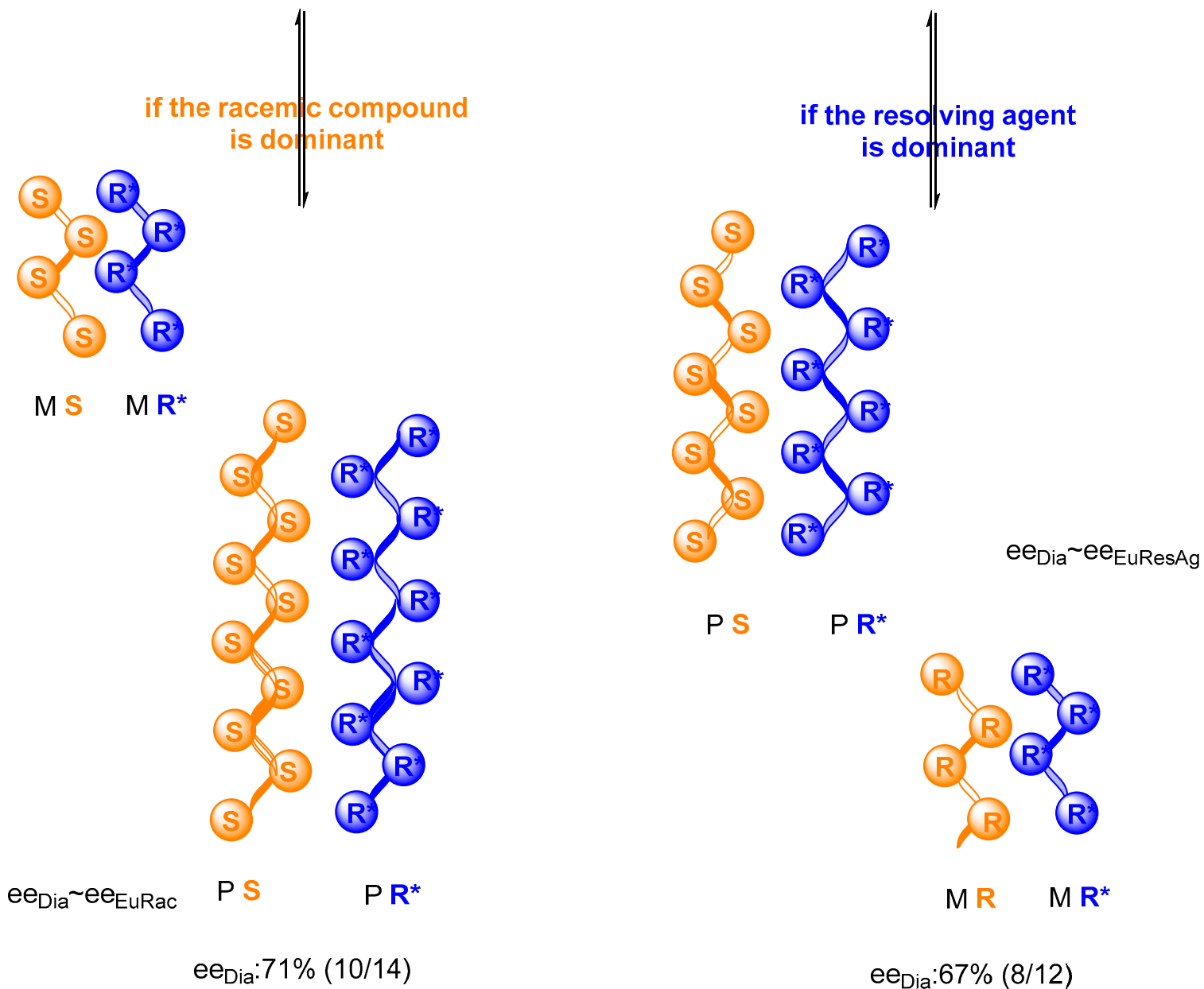

Figure 3. Possibilities of reactions between the racemic compound (SR) and the resolving agent ( $R^{*}$ ) for putative eutectic compositions-a hypothetical example. 
<smiles>CN[C@@H](C)Cc1ccccc1</smiles>

R-MeAn<smiles>CC(Cc1ccccc1)Cc1ccccc1</smiles>

S-MeAn<smiles>O=C[C@H](O)[C@@H](O)[C@H](O)C(=O)O[Na]</smiles>

$R, R$-TA
$R$-MeAn. $(R, R)-\mathrm{TA}$

ee $_{\text {Dia }}: 95 \% \quad F: 0.64$

Figure 4. Resolution of methamphetamine (2-methylamino-1-phenylpropane) with $(R, R)$-tartaric acid.

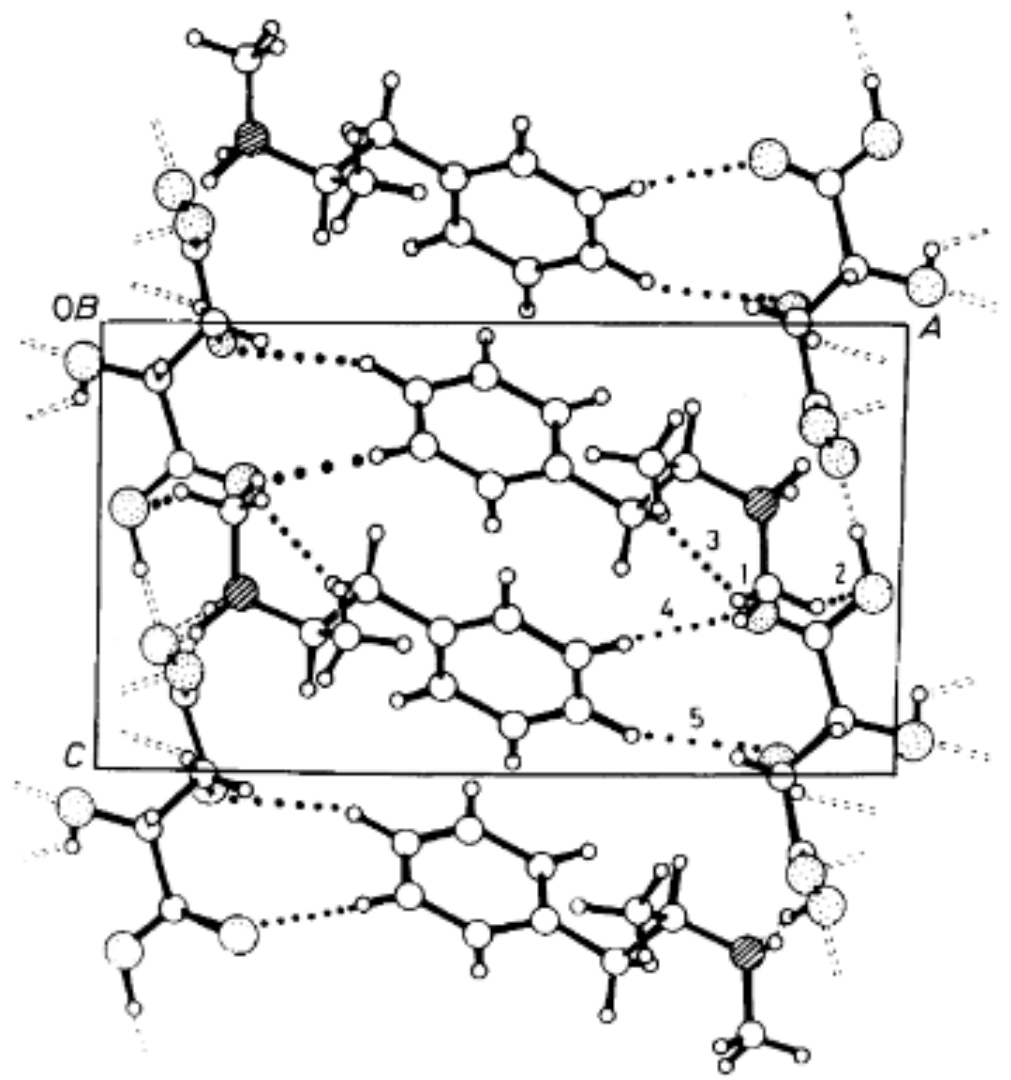

Figure 5. The packing arrangement of $(R)-M e A n .(R, R)$-TA viewed along the $\mathrm{b}$ axis. Dotted lines represent $\mathrm{C}-\mathrm{H} \ldots$. O contacts $1-5$ [20].

The reaction mixture contains the supramolecular helical associates of $(R)$-MeAn and $(S)$-MeAn and associates of $(R, R)$-TA, which form head-to-foot supramolecular helical associates. The reaction produces acidic salt forming supramolecular helical associates of $(R)-$ MeAn and $(R, R)$-TA, which then form an antiparallel double helix.

Simultaneously, the resulting double helices, also with an antiparallel orientation, react with the acidic salt forming helical structures and disintegrate into further double helices by replication. When the concentration of the double helix structures reaches the limit of the solubility, the crystallization of the $(R)$-MeAn. $(R, R)$-TA diastereomeric salt begins (Figures 3 and 6), which may become autocatalytic.

It is reasonable to assume that the structure (code) of the chiral molecules determines the stoichiometry of crystallization and replication of helical supramolecular structures. Simultaneously, it also proves that the formation and replication of antiparallel double helices can occur not only by the formation of covalent bonds but also with secondary binding forces.

In addition to the resolution of the racemic bases shown so far, we present the resolutions of other racemic compounds with chiral acids (Table 1). It can be seen that the racemic MeAn may be resolved with both $(R, R)$-DPTA and $(R, R)$-TA (Table 1 , Entries 1 and 2$)$; however, in the case of $(R, R)$-DPTA, lower resolvability was achieved. 
Table 1. Resolutions of racemic compounds with chiral acids.

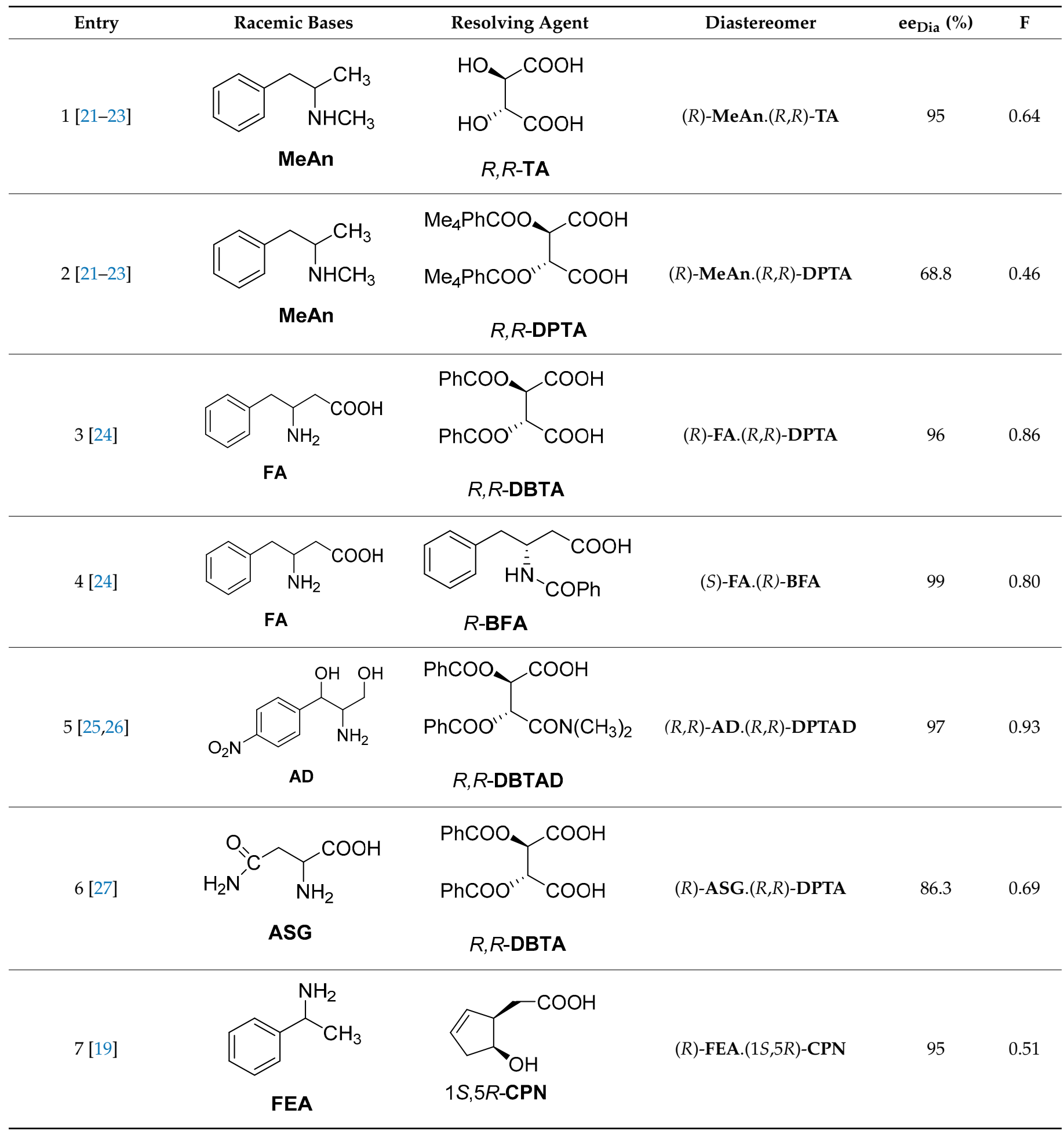



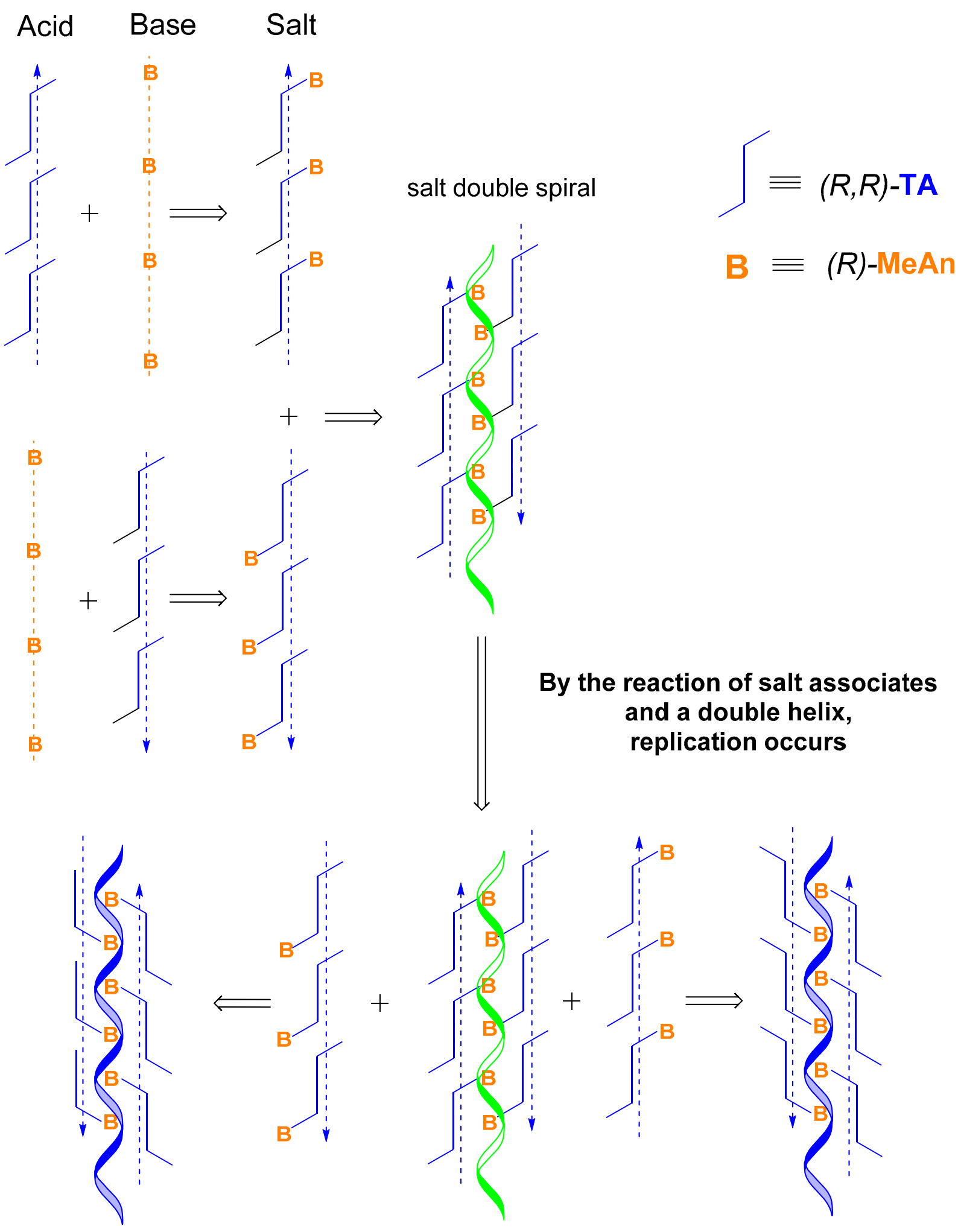

salt double spiral

salt double spiral

Figure 6. Retro-synthesis of the crystalline diastereomeric salt.

Another phenylisopropyl derivative (AD) allowed excellent enantiomeric separation using $(R, R)$-DPTAD (Entry 5). However, free amino acids (FA, ASG) may be resolved effectively using $(R, R)$-DPTA (Entries 3 and 6), although the carboxyl group was not protected. The free racemic FA also allows good separation with its benzoylated enantiomer 
(Entry 4). In the seven resolutions presented, the stoichiometry of the diastereomeric salts $\left(e_{\text {Dia }}\right)$ was clearly determined by the eutectic composition of the enantiomeric mixtures of the resolving agent ( $e_{\text {Dia }} \sim e_{\text {ResAg }}$ ). It is surprising how similar the structures of these diastereomeric salts are, as if they were seven-membered ring structures (chelate structure) (Figure 5 and Table 2).

Based on the calculated results of the diastereomeric bitartrate (Figure 5), sterically determined antiparallel tartrate chains recognize the corresponding enantiomers to form the double helix structure. Using molecular simulation ${ }^{1}$ based on the X-ray diffraction, the formed spatial structure is illustrated (Figure 7). It can be seen that this structure can only be formed if the acid (resolving agent) and the base are located in the form of double helix associates.
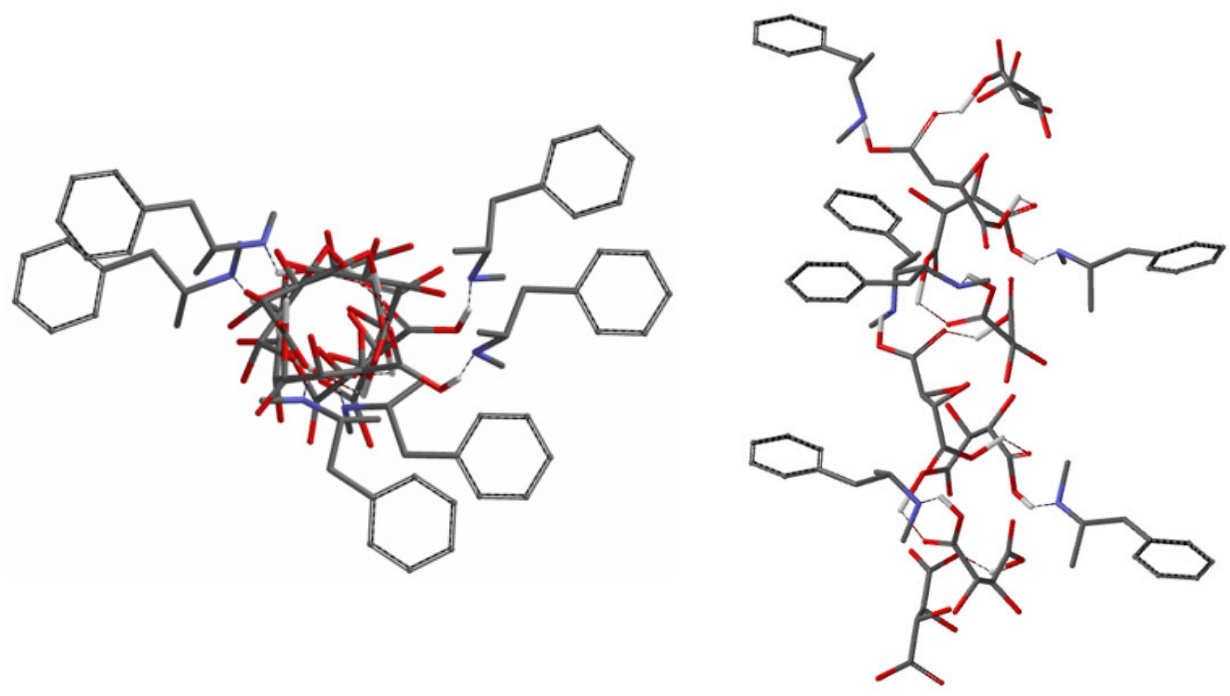

Figure 7. Top and side views of the double helix structure on the $(R)-\mathbf{M e A n} .(R, R)$-TA diastereomeric salt.

The reaction of helical acid and base associates produces helical salt associates that have antiparallel orientation and form helical double spirals. Helical double spirals can be duplicated by replication from their helical salts (Figure 6).

Further, the resolution results of racemic acids (mainly $\mathrm{N}$-acetylated amino acids) were introduced (Table 3, Entries 8-16) with a single base resolving agent. It is striking that the environment of the diastereomeric salts of these resolutions is essentially the same as described above (Tables 1 and 2, Entries 1-7).

In these cases, the $X$ substituent has the greatest effect on the result of the separation. Although ( $e_{\mathrm{Dia}} \sim \mathrm{ee}_{\mathrm{ResAg}}$ ) is also valid for these resolutions, clearly more modest separations (F) were obtained with the basic resolving agents. It is likely that the acid components of the diastereomers allow for weaker secondary bonds (Table 2).

Table 2. Seven-membered ring structure of the diastereomeric salts from Tables 1 and 3.

Diastereomer 7 $\quad$ Diastereomers 1-3,6


It was known that the resolvability of enantiomeric mixtures into single enantiomeric and racemic fractions is a nonlinear function of the initial enantiomeric ratio. From the mixture of enantiomers purer than the eutectic composition, the enantiomer crystallizes, while the racemic fraction crystallizes when the mixture of enantiomers is below this level of purity. This phenomenon has been explained by some of the different reactions of supramolecular associates, while other studies [16-23] have explained it by the selfdisproportionation of enantiomeric mixtures (SDE).

Table 3. Resolutions of racemic compounds with chiral bases.

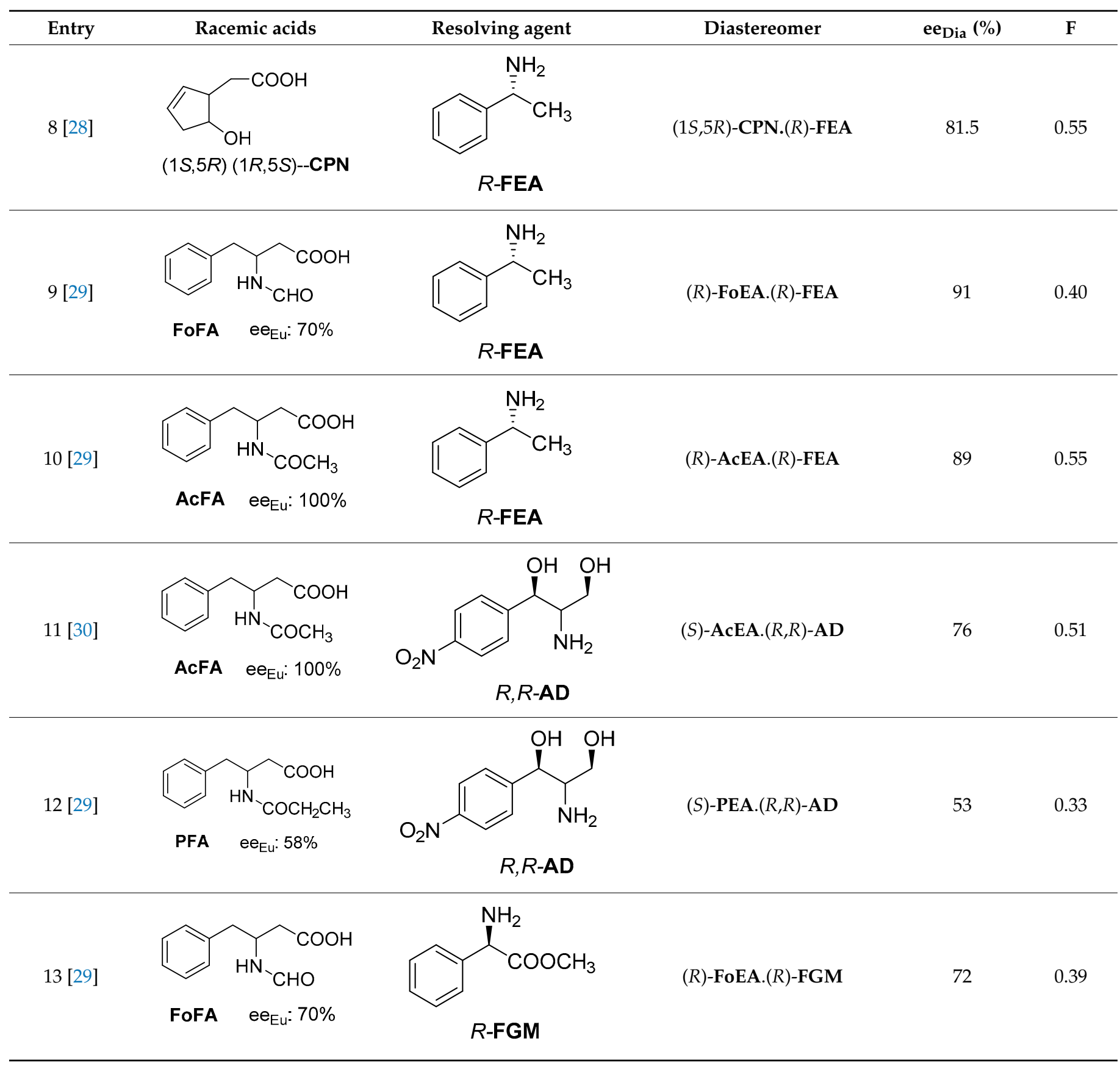


Table 3. Cont.

Entry

${ }^{1}$ Molecular modeling software: Spartan'18 v.1.4.4/2019

It has been found that enantiomeric mixtures, i.e., the racemic compound and the resolving agent (a third chiral molecule), are also capable of self-disproportionation in a common solution by the interactions (reaction) of supramolecular helical associates forming the conformers of the chiral molecules present.

\section{Conclusions}

As a result, the eutectic composition of the enantiomeric mixture isolated from the crystalline diastereomeric salt (depending on the solvent, crystallization conditions, and time) agrees well with the eutectic compositions of the racemic compound or enantiomeric mixtures of the resolving agent (ee $\mathrm{Dia}_{\mathrm{Dia}} \sim \mathrm{ee}_{\mathrm{EuRac}}$ or $\sim \mathrm{ee}_{\mathrm{EuRac}}$ ).

Although the resolving agent is present only in single enantiomeric form during the resolution, it is able to force a ratio corresponding to its eutectic composition on the diastereomeric salt.

This is made possible by the fact that the chiral molecules present form homo- and heterochiral supramolecular associates (corresponding to their eutectic composition) and react with each other. The salts corresponding to the diastereomer thus form an antiparallel helical double spiral structure, which is capable of replication. Crystallization begins from a supersaturated solution of the structures thus formed, which maintain an active equilibrium with the solution until they are separated.

Simultaneously, all this also proves that a chiral molecule validates the code of its reaction with other chiral molecules with its molecular geometry.

Author Contributions: D.F.B. and E.P. wrote the paper together, and it is based on their own experimental results. All authors have read and agreed to the published version of the manuscript.

Funding: This research received no external funding.

Institutional Review Board Statement: Not applicable.

Informed Consent Statement: Not applicable.

Data Availability Statement: Not applicable. 
Acknowledgments: The authors thank Emeritus Elemér Fogassy for his valuable and constructive suggestions during the planning and development of this research work. His willingness to give his time so generously has been very much appreciated. This work was supported by the National Research, Development and Innovation Office-NKFIH through OTKA grants 124180.

Conflicts of Interest: The authors declare no conflict of interest.

\section{References}

1. Pálovics, E.; Szeleczky, Z.; Fődi, B.; Faigl, F.; Fogassy, E. Prediction of the efficiency of diastereoisomer separation on the basis of the behaviour of enantiomeric mixtures. RSC Adv. 2014, 4, 21254-21261. [CrossRef]

2. Pálovics, E.; Szeleczky, Z.; Fogassy, E. Influence of Helical Structured Supramolecular Associates and that of Eutectic Composition on the Distribution of Enantiomeric and Diastereomeric Mixtures between Phases. Chem. Bull. Politeh. Univ. 2016, 61, 40-43.

3. Pálovics, E.; Fogassy, E. A Presumable Mechanism of the Separation of Diastereomeric and Enantiomeric Mixtures. J. Chromatogr. Sep. Tech. 2017, 8, 391.

4. Pálovics, E.; Fogassy, E. Aszimmetrikus vegyületek keverékeinek viselkedése és elválasztása. Magyar Kémiai Folyóirat 2018, $124,56$. [CrossRef]

5. Soloshonok, V.A. Remarkable Amplification of the Self-Disproportionation of Enantiomers on Achiral-Phase Chromatography Columns. Angew. Chem. Int. Ed. 2006, 45, 766-769. [CrossRef]

6. Soloshonok, V.A. Phenomenon of Optical Self-Purification of Chiral Non-Racemic Compounds. J. Am. Chem. Soc. 2007, 129, 12112-12113. [CrossRef]

7. Han, J.; Kitagawa, O.; Wzorek, A.; Klika, K.D.; Soloshonok, V.A. The self-disproportionation of enantiomers (SDE): A menace or an opportunity? Chem. Sci. 2018, 9, 1718-1739. [CrossRef]

8. Kodama, K.; Yi, M.; Shitara, H.; Hirose, T. Chirality switching in the enantioseparation of 2-hydroxy-4-phenylbutyric acid: Role of solvents in selective crystallization of the diastereomeric salt. Tetrahedron Lett. 2020, 61, 151773. [CrossRef]

9. Tumanova, N.; Seiler, V.; Tumanov, N.; Robeyns, K.; Filinchuk, Y.; Wouters, J.; Leyssens, T. Structural Analysis of dPhenylglycinamide Salts Uncovers Potential Pitfalls in Chiral Resolution via Diastereomeric Salt Formation. Cryst. Growth Des. 2019, 19, 3652-3659. [CrossRef]

10. Simon, M.; Donnellan, P.; Glennon, B.; Jones, R.C. Resolution via Diastereomeric Salt Crystallization of Ibuprofen Lysine: Ternary Phase Diagram Studies. Chem. Eng. Technol. 2018, 41, 921-927. [CrossRef]

11. Córdova-Villanueva, E.N.; Rodríguez-Ruiz, C.; Sánchez-Guadarrama, O.; Rivera-Islas, J.; Herrera-Ruiz, D.; Morales-Rojas, H.; Höpfl, H. Diastereomeric Salt Formation by the $\gamma$-Amino Acid RS-Baclofen and L-Malic Acid: Stabilization by Strong Heterosynthons Based on Hydrogen Bonds between RNH3+ and COOH/COO- Groups. Cryst. Growth Des. 2018, 18, 7356-7367. [CrossRef]

12. Sorochinsky, A.E.; Aceña, J.L.; Soloshonok, V.A. Self-Disproportionation of Enantiomers of Chiral, Non-Racemic Fluoroorganic Compounds: Role of Fluorine as Enabling Element. Synthesis 2013, 45, 141-152. [CrossRef]

13. Soloshonok, V.A.; Roussel, C.; Kitagawa, O.; Sorochinsky, A.E. Self-disproportionation of enantiomers via achiral chromatography: A warning and an extra dimension in optical purifications. Chem. Soc. Rev. 2012, 41, 4180-4188. [CrossRef]

14. Ueki, T.; Yasumoto, M.; Soloshonok, V.A. Rational application of self-disproportionation of enantiomers via sublimation-A novel methodological dimension for enantiomeric purifications. Tetrahedron Asymmetry 2010, 21, 1396-1400. [CrossRef]

15. Sorochinsky, A.; Soloshonok, A. Self-disproportionation of Enantiomers of enantiomerically enriched Compounds. Top Curr. Chem. 2013, 21, 301-340. [CrossRef]

16. Sorochinsky, A.E. Optical Purifications via Self-Disproportionation of Enantiomers by Achiral Chromatography: Case Study of a Series of $\alpha$-CF3-containing Secondary Alcohols. Chirality 2013, 25, 365-368. [CrossRef]

17. Marthi, K.; Larsen, S.; Ács, M.; Bálint, J.; Fogassy, E. The Optical Resolution of 3-(2'-Hydroxy-2'-phenylethyl)-2-thiazolidinimine and the Crystal Structure of the (2R,3R)-O,O'-Dibenzoyl Hydrogen Tartrate Salt of the (S)-(+)-Enantiomer. Acta Chem. Scand. 1995, 49, 20-27. [CrossRef]

18. Bosits, M.H.; Pálovics, E.; Madarász, J.; Fogassy, E. New Discoveries in Enantiomeric Separation of Racemic Tofisopam. J. Chem. 2019, 4980792. [CrossRef]

19. Czugler, M.; Csöregh, I.; Kálmán, A.; Faigl, F.; Ács, M. Crystal structures of the diastereomeric salt pair of the prostaglandin intermediate 1R, 2S(+)-cis-2-hydroxycyclopent-4-enylacetic acid with S- and R- 1-phenylethylamine. J. Mol. Struct. 1989, 196, 157-170. [CrossRef]

20. Fogassy, E.; Ács, M.; Faigl, F.; Simon, K.; Rohonczky, J.; Ecsery, Z. Pseudosymmetry and chiral discrimination in optical resolution via diastereoisomeric salt formation. The crystal structures of (R)- and (S)-N-methylamphetamine bitartrates (RMERTA and SMERTA). J. Chem. Soc. Perkin Trans II 1986, 11, 1881-1886. [CrossRef]

21. Rusznák, I.; Soós, R.; Fogassy, E.; Ács, M.; Ecsery, Z. Eljárás optikailag aktív N-alfa-dimetil-béta-fenil-etilamin antipódok előállítására. Hung. Pat. no. 169845, 1976.

22. Rusznák, I.; Soós, R.; Fogassy, E.; Ács, M.; Ecsery, Z. Eljárás D- és L-N-alfa-dimetil-béta-(p-htt-fenil)-etilaminok előállítására. Hung. Pat. no. 169844, 1976.

23. Kozma, D.; Madarász, J.; Kassai, C.S.; Fogassy, E. Optical resolution of N-methylamphetamine via diastereoisomeric salt formation with 2R,3R-O,O'-di-p-toluoyltartaric acid. Chirality 1999, 11, 373-375. [CrossRef] 
24. Ács, M.; Faigl, F.; Fogassy, E. Diastereomer salts of phenylalanine and N-acyl derivatives for the separation of optically active phenylalanine and N-acyl derivatives. WO 8503932 A1 19850912, 1985.

25. Kőnig, R.; Földy, Z. Eljárás optikailag aktív stereomerek elválasztására. Hung. Pat. 146896, 1958.

26. Soós, R.; Fogassy, E.; Nagy, F.; Horváth, K.; Boros, K.; Résey, F.; Nagy, K.; Galambos, T.; Alföldi, I. Eljárás D-(-)-treo-(4'-nitro-fenil)2-amino-propán-1,3-diol eloállítására. Hung. Pat. 163526, 1984.

27. Soós, R.; Fogassy, E.; Gressay, J.; Erdélyi, A. Eljárás aszparagin nagy tisztaságú izomerjeinek elóállítására. Hung. Pat. 165115, 1981.

28. Tőke, L.; Szabó, G.; Fogassy, E.; Ács, M.; Nagy, L.; Árvai, L. Eljárás a racém cisz-2-hidroxi-ciklopent-4-én-1-il-ecetsav alkálifémsóinak és laktonjának optikailag aktív alfa-fenil-etilaminnal történó rezolválására. Hung. Pat. 177583, 1978.

29. Pálovics, E.; Közös, A. Rokon Molekulaszerkezetú Vegyületek a Reszolválás Folyamataiban. Ph.D. Thesis, Budapest University of Technology and Economics, Budapest, Hungary, 2008.

30. Geipel, H. Die Racematspaltung des DL-Phenylalanins mit L(+)-threo-1-[p-Nitrophenyl]-2-aminopropandiol-(1,3). J. Prakt. Chem. 1959, 9, 104-106. [CrossRef] 